\title{
The 6+1 Trait Writing Model to Build Up Students' Writing
}

\author{
Kalsum \\ Institut Agama Islam Negeri Parepare \\ Email: kalsumkhalil@gmail.com
}

\begin{abstract}
This study aims to investigate the effectiveness of the $6+1$ trait writing model on students' writing achievement. It is focused on the students' improvement based on the five processes of writing which connected with $6+1$ trait writing model. To get the aim of the study, this study implemented quantitative methods with pre-experimental method with one group pre-test and post-test design. The study was conducted on 25 students' of Pondok Pesantren DDI At-Taqwa Jampue Pinrang. Written test is used as instrument. In order to know the improvement of each categories of writing, the students' result were analyzed by using Analytic Rubrics Six-Trait. Based on the analysis, it is found that the students' writing was improved in four out of six traits which are ideas, organization, voice and conventions traits. The $6+1$ trait writing model improved the students' writing while the teacher can monitor students' writing progress from every aspect of writing and help them to write well.
\end{abstract}

Keywords: Writing, The 6+1 Trait Writing Model, Students' Writing

\section{INTRODUCTION}

Writing is known as one of the most important skills but the difficult academic skills also. The students usually need more time to master it. It usually takes so much time for students to master competently and hence tends to be a boring lesson. (Erikson, 2015). Writing is an indispensable skill for all students for success in a great number of works as well as for academic growth.

For Indonesian students, writing is not an easy process for the majority of them (Rahman and Weda
2018). The students have a lot of problems when they are started to write. Without the basic writing skills needed for success, students face difficulties at writing as they reach college. (Quora \& Zahran, 2018).The root of writing difficulties may recline in the improper absence of instruction. A number of studies proved the cause behind writing problems are: 1) worksheets and prompts do not guide to thoughtful writing. They only serve one purpose which is writing to make the teacher satisfy 2) the total time for students to spend writing tasks is not enough. Therefore, there is a need to double the 
amount of time for writing tasks. (Graham \& Perin)

3) additionally, teachers are faced with local and national demands. The absence system of standard, curriculum, and instruction increases the writing challenge that teachers have to overcome. (2004)

The $6+1$ writing model shifts the focus from traditional instruction to develop writing skills and provide feedback on students' writing. This model instruction provides students with criteria for developing writing skills as well as critical thinking by providing a clear explanation of why students received the score they got (Culham, 2003). The target of this study is to recognize the efficiency and the effectiveness of the $6+1$ trait writing model in building up the students' writing development.

\section{Writing}

Writing is the most important skill that students need to develop in order to prove their English. Before master in writing, the students should be able to listen, to speak, and to read. Brown states that trends in teaching writing of ESL and other foreign languages are integrated with teaching other skills, particularly listening and speaking (Brown, 2001). For example, when the teacher gives a task, the students may collect information from any sources; a radio, a television, a magazine's internet or directly communicating with an expert which related to their task. While doing the research, they use their listening, reading, and speaking skills. Based on their information, they start to write the task. Hence, writing is not an easy skill to master. The students need to practice more and more.

Writing belongs to productive skill rather than perceptive ones which it produces a message to communicate. Spratt, Pulverness, and William state that writing and speaking belong to productive skills. They stated that speaking, writing, particularly, involve producing language rather than receiving it (Melanie, 2005). The theory also supported by Wright who stated speaking and writing are both productive skills.

In writing, the students cannot only focus on their output (final writing). The students should pay attention to the process or steps in writing in order to produce good writing. Good writing means good in terms of language, content, purpose, and referred reader. There are some linguists that given the writing process based on their theory.

Hyland illustrates the stage of writing to give students a clear understanding that the writing process is significant to produce good writing (Hyland, 2004).

1. Selection of topic. It can be done by both students and teachers.students can find their own topic or with the teacher's help. Another way, teachers can decide on the topic that students should choose to write.

2. Prewriting. In this stage, students are involved in brainstorming, collecting data, note-taking, and outlining.

3. Composing/drafting. In this stage, students begin to write their ideas down on paper.

4. Revisions. It can be conducted by teachers or peers. It is about responding to ideas, organization of the text, and text style.

5. Proofreading or editing. In this stage, there will be checking and correcting form, evidence, layout, and so on.

6. Evaluation. The teacher judges the progress that 
students achieved. The student should perform their progress by time.

7. Publishing. It means allowing people to read the writing as the final product. It can be presented in class or showing on notice boards, or even on the website.

8. Follow-up tasks. It is conducted to conclude the weakness of students writing. By holding this stage, students are hoped to have better writing.

\section{The 6+1 Trait Writing Model}

"Six-trait writing" was developed in the 1980s as an approach to classroom assessment of student writing that would provide students and teachers with more structure to understand how to write well (Culham, 2003). The method was built on the descriptive and theoretical work of Diederich and Purves, two pioneers in the use of classroom-based analytical assessments of student writing to inform diagnostic decisions about writing instruction. It incorporates aspects of process writing, including their cursive use of planning, drafting, assessment, and revision developed through the work of Emig (1971), Flower and Hayes (1981), Applebee (1986), and others.

The $6+1$ Trait Writing model can be used to provide additional structure, content, and guidance to instruction that is based on the writing process (or "writing workshop" format, which began as a method that gave students little specific guidance on writing. According to Pritchard and Honeycutt, the understanding of what constitutes the writing process instructional model has evolved since the 1970s, when it emerged as a pedagogical approach.
In the early years, it was regarded as the anondirectional model of instruction with very little teacher intervention (Pritchard \& Honeycutt, 2006). Although current process writing instruction may include a prescriptive structure involving planning (prewriting), writing, and rewriting. These steps may be applied in a formulaic manner that does not focus attention on the interplay between the intended audience, the author's voice, ideas and organization, word choice, and sentence fluency (Bascolo, 2008). Writing instruction may be enriched by an explicit focus on particular traits of writing.

The 6+1 Trait Writing model is not an alternative writing curriculum designed to replace existing writing programs in schools, but rather an additional, complementary set of tools to aid in conceptualizing, assessing, and describing the qualities of writing. It is used in conjunction with existing writing curricula to provide a framework for classroom writing instruction, feedback, and dialogue that is designed to improve the ability of $\mathrm{K}-12$ teachers and students to plan, evaluate, discuss, and revise their writing (Culham, 2003).

The model includes a framework of instructional strategies (classroom practices) that are used to facilitate the integration of assessment with instruction, targeting seven traits of effective writing: ideas, organization, voice, word choice, sentence fluency, conventions, and presentation. The $6+1$ Trait Writing model can be used within language arts instruction or for applications in which writing is integrated with other academic subjects. Because the model is intended to be integrated with existing writing curricula and instruction, rather than replacing them, teachers have flexibility in how 
this is done, including the intensity with which the suggested practices are used with students.

Higgins, Miller, and Wegman (2006) affirmed that the 6+1 Traits fit effectively into the writing process and make students' writing more focused and purposeful. The Traits method integrates assessment with the writing curriculum and students use the rubric as a tool for revision. Teachers provide instruction on the $6+1$ Traits during mini-lessons that assist students in the revision process.

The $6+1$ trait writing model provides teachers with a shared vision and vocabulary for describing the qualities of good writing, these are ideas, organization, voice, word choice, sentence fluency, and conventions. It also gives a common language for writing assessment so we can provide students with precise, complete feedback on their writing performance and needs. The model of $6+1$ trait writing model for assessment and instruction is described as follow:

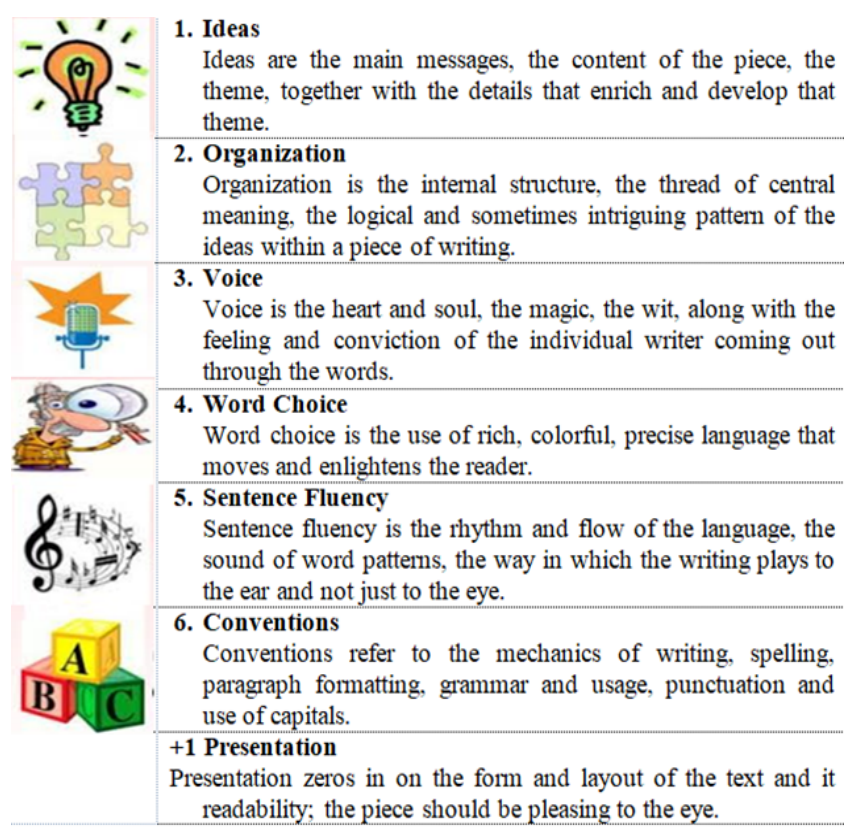

Picture 1. The 6+1 Trait Writing Model
Harmer stated that students should pay attention not only to what to write but also how to write. There are actually several strategies to write well. The $6+1$ trait writing model cannot be separated from the writing process. The $6+1$ trait writing model actually connects with the writing process. It was supported by Culham which states that the trait represents the crucial components of writing: ideas, organization, word choice, sentence fluency, convention, and presentation. The implementation of this model gives the improvement of students' writing and critical thinking.

In this study, the $6+1$ trait writing model provided the teacher to monitor the students' writing progress in every aspect of writing. The teacher can assess and provide constructive feedback on students' writing in every aspect of the writing assessment. This feedback is very useful so that students' writing is getting better in every aspect of writing. The teacher combines the $6+1$ trait writing model as a writing learning model and Analytic Rubrics Six-Trait as a measuring tool for students' writing development.

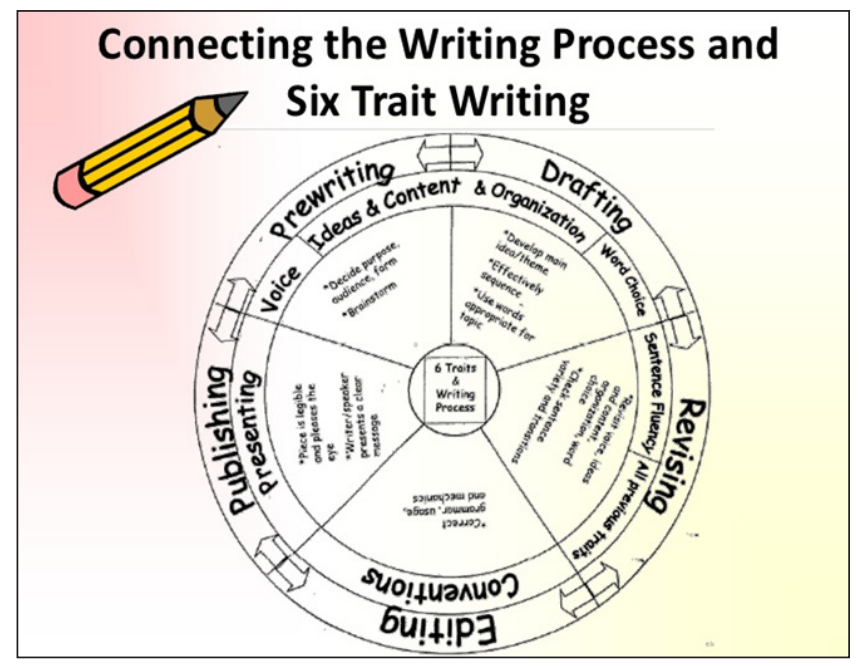

Picture 2. The correlation of the writing process and the $6+1$ trait writing model 


\section{METHOD}

This study applied the pre-experimental method with one group pre-test and post-test design. The samples of this study were the 25 students of Pondok Pesantren DDI At-Taqwa Jampue Pinrang. The instrument of this study is a written test. The analytic rubrics six-trait as assessment instrument used to assess the students' writing result. To get the data, the students' are given pre-test in the beginning of meeting. For four next meetings, the students are given $6+1$ trait writing model treatment. In the last meeting, the posttest is given as the result of the treatment. For data analysis, the students' writing result is analyzed by using the analytic rubric six-trait.

\section{FINDING AND DISCUSSION}

This section presents students' writing data in which each aspect is analyzed and compared at the beginning and end of the test.

Every treatment represented one trait of writing model connecting with the writing process. The treatments are: 1) Prewriting, 2) Drafting, 3) Revising, and 4) Editing. The writer makes an analysis by using SPSS to know the students' improvement in every trait. The result of the test is described as follows:

The hypothesis emphasized that the $6+1$ traits writing model able to build up the students' writing skills. The alternative hypothesis stated that there would be an achievement of the students. The result of the effect of the $6+1$ trait writing model also showed some improvement from the students. Between six-component writings, there are four components that give an improvement: ideas, organization, voice, and conventions. The other components, word choice, and sentence fluency did not give any improvement for students.

It is important to note that all student participants in the study increased their scores from pretest to posttest in one or more component areas as a result of the instruction. This study resulted in an even split between the six component areas on the rubric. The students make a significant improvement in four component areas of rubric; ideas, organization, voice, and conventions. Two others give no significant improvement for students; word choice and sentence fluency.

There are several possible explanations for these findings. Many connections can be made from the results of this study to prior research. To begin with, the 6+1 Trait Writing Model incorporates a large amount of children's literature within the lessons. The theory behind the method is that children learn to write like real authors and use similar language, thus the six traits of ideas, organization, voice, word choice, sentence fluency, and conventions become common vocabulary.

The six components of traits gave a significant impact on students' writing improvement. Among the six traits, four components are positive in increasing their writing ability. It was supported by the research of Arter et al. which is conducted a similar study to this one involving six classes of fifthgrade students. These researchers concluded that students in the treatment group (6+1 Trait Method) received significant gains in one out of six trait areas, with two other areas approaching significance. The 
current study resulted in significant gains in two out of four component areas.

According to the data, the $6+1$ traits is able to build up the students' writing skill. It means that the students are confident in writing their tasks. If this research is done in a more long time, the students' writing ability is more improved. As reported by Jarmer et al. reported in their study at Jennie Wilson Elementary School, that after three years of implementation of the $6+1$ Trait Writing Method in all grades, student standardized test scores increased each consecutive year. Learning to write through the use of literature and the $6+1$ Traits not only is effective in raising test scores but also in creating strong and confident writers.

Higgins, Miller, and Wegmann concluded from their research that by combining the writer's workshop, process writing, and instruction on the $6+1$ Traits helps students meet state standards in writing and develops skills needed to be effective writers.

Cotton \& Northwest Regional Educational Lab reported on what research says about teacher training and student writing achievement. They concluded from the research that staff development programs do not necessarily have to follow a specific model in order to be effective. Training teachers to use a process approach to writing with ongoing skillbuilding lessons are essential for effective teacher in-service programs to improve student writing achievement.

The students at Pondok Pesantren DDI AtTaqwa still lack in organize their idea and the content of their writing. By using the $6+1$ traits writing model, the students are introduced and taught how to organize their writing well. The teacher's instruction helps students to write well by doing the training in their daily learning at school. Using the 6+1 Trait method in the classroom as part of the daily writing instruction is effective when teachers are trained in the content and its presentation. Corden concluded from his study that providing models for writing through texts helps children to develop their awareness of how texts are constructed. He also stated that the children in the study gradually developed a literary language from discussing texts and were able to apply it to their own writing. This researcher concluded through the findings of the current study that both quality instruction and time for writing improve student writing achievement.

The use of the $6+1$ traits writing model also takes an important part in students' writing achievement. The rubric may use as an indicator to measure the students' improvement in every component of the writing process. It supported by the study of Arter et al which focused on the use of the $6+1$ Trait rubric and its effects on student writing achievement. Teaching students about rubrics and using them as a guide for their writing does improve writing skills. They stated that one reason for the success of the $6+1$ Trait Writing Model is its use of a specifically-created rubric encompassing the six traits for the component areas.

Schamber and Mahoney (2006) also completed a study involving the use of rubrics. They determined that using rubrics develops critical thinking skills in students by teaching them to self-evaluate their 
own writing. It provides clear expectations of what a successful paper entails. The rubric used in the current study was similar to the $6+1$ Trait rubric involving four component areas: content development, organization, voice/word choice, and conventions. Prior research showed involving the reading-writing connection, using children's literature as a model for writing, requiring increased time for writing as well as implementing strategic instruction, and using rubrics lead to increased student writing achievement. The $6+1$ Trait Writing Model method used in the treatment group of this study included all of these things. These strategies were also included on a smaller scale in the control group, and as a result, both groups experienced significant gains in achievement.

\section{CONCLUSION}

The goal of this study is to build up the students' writing achievement. Besides that, the rubric also is used as an indicator to measure the students' writing over time. The results showed that it did significantly improve writing, four of six the component areas on the rubric are improved in increasing the writing achievement. However, other implications can be gathered from the study. It also can be the teacher's evaluation of the student's progress in learning writing.

First, in order to improve student achievement in writing, teachers need to provide reserved time for writing on a daily basis. Teachers need to maximize instructional time as much as possible so that writing instruction does not get slighted or ignored. The second thing that can be learned from the study is that schools need to choose a writing curriculum and then train their teachers on how to implement it. The $6+1$ Trait Model has been proven effective as a method to teach students to write like real writers and to create authentic writing pieces. The process approach to writing method has also been proven effective.

\section{REFERENCES}

Arter, J.A., Spandel, V., Culham, R., \& Pollard, J. 1994. "The Impact of Training Students To Be Self-Assessors of Writing." Paper presented at the American Education Research Association, New Orleans, LA.

Bellamy, P.C. 2000. "Research on Writing with the 6+1 Traits." Portland, OR: Northwest Regional Educational Laboratory.

Brown, Douglas. 2001. "Teaching by Principles: An Interactive Approach to Language Pedagogy." $2^{\text {nd }}$ Edition. San Francisco: Longman.

Cassany, D. 1999. "Construir La Escritura." Barcelona: Paidos.

Culham, R. 2003. "6+1 Traits of Writing: The Complete Guide.”New York: Scholastic Inc.

Cunningham, P.M. Cunningham \&Allington, R.L. 1999. "Classrooms That Work: They Can All Read and Write." New York: Addison-Wesley Longman Publishers, Inc.

Rahman, Fathu, and Sukardi Weda. 2018. "Students' Perceptions in Appreciating English Literary Works through Critical Comment: A Case Study at Hasanuddin University and Universitas Negeri Makassar." Asian EFL Journal 20 (3): 149-172.

Garcia, J. 2003. “Educar Para Escribir.” Mexico: Editorial LIMUSA, S.A.

Graham, S., \& Perin, D. 2007. "Writing Next: Effective Strategies to Improve Writing of Adolescents in Middle and High Schools: A report to Carnegie Corporation of New York." Washington DC: Alliance for Excellent Education. 
Harmer, J. 2004. "How to Teach Writing."UK: Longman.

Higgins, B., Miller, M. \&Wegmann, S. 2006. "Teaching to the test...not! Balancing Best Practice and Testing Requirements in Writing." Reading Teacher, 60 (4), 310-319. Retrieved December 6, 2008, from the Academic Search Premier Database.

Hyland, K. 2004. "Second Language Writing." New York: Cambridge University Press.

Kozlow, M., \& Bellamy, P. 2004. "Experimental Study on the Impact of the 6-1 Trait Writing Model on Student Achievement in Writing." Northwest Regional Educational Laboratory. Center for Research, Evaluation, and Assessment, Assessment Program.

Marzano, R.J. 2003. "What Works in Schools: Translating Research into Action." Alexandria, VA: Association for Supervision and Curriculum Development.

Nunan, David. 2003. Practical English Teaching. America: Mc Graw Hill Companies.

Pritchard, R. J., and R.L Honeycutt. 2006. "The Process Approach to Writing Instruction: Examining Its Effectiveness." In C.A. Macarthur, S. Graham, and J. Fitzgerald (Eds.), Handbook of Writing Research. New York: Guilford Press.
Spandel, V. 2005. "Creating Writers Through 6 Trait Writing Assessment And Instruction." Boston, M.A: Pearson Education, Inc.

Togatotop, Erikson. 2015. "Teaching Writing with A WebBased Collaborative Learning." International Journal of Economics and Financial Issues, 5.

Trudy, Wallace, et al. 2004. "Teaching Speaking, Listening, and Writing." International Academy of Education: Education Practice Series 1-14.

Williams, Melanie, et al. 2005. "The TKT Course." Cambridge: Cambridge University Press.

D.Jarmer, Kozol, M., Nelson, S., \& Salsberry, T. 2000. "Six-Trait Writing Model Improves Scores at Jennie Wilson Elementary." Journal of School Improvement, 1 (2).

Quora, Ali, and A. Zahran. 2018. "The Effect of the 6+1 Trait Writing Model on ESP University Students Critical Thinking and Writing Achievement." English Language Teaching, (11) 